\title{
Folk Culture of Garhwal Himalaya: Ethnic Food and its medicinal value - A brief analysis
}

Pratibha Baluni $^{1} \cdot$ Suniti Kumar Kuriyal $^{2} \cdot$ Kusum Dobriyal $^{3 *}$

${ }^{1}$ Department of Botany, S. D. M. Govt. P. G. College Doiwala, Deharadun-248001, Uttarakhand, India.

${ }^{2}$ Department of Botany, S.D.S.University Campus, Rishikesh- 249201, Uttarakhand, India.

${ }^{3}$ Department of Sanskrit, H. N. B. Garhwal University (A Central University), Campus Pauri-246001, Pauri Garhwal, Uttarakhand, India.

*Corresponding author: kusumdobriyal62@rediffmail.com

Received: 15.11.2021; Revised: 17.12.2021; Accepted: 21.12.2021

CSociety for Himalayan Action Research and Development

\begin{abstract}
Garhwal Himalaya is rich in its cultural diversity since ancient time. Types of food grains and the recipes used in common and in particular during specific occasions is an important aspect of culture of Garhwal Himalayan folk. Though an enormous number of plant species, which are identified as food and medicines by the folk, are naturally available or are grown in this soil, some very specific food items (Ragi, Amranthur, Ogal, Jwar, Maize, Rajma, Gahat, Bhatt, Urd, Suntha, Lobihiya, Moong, Til, Bhang jeera, Jau, Red Rice, etc.), their specific recipes, and medicinal value is discussed in the paper. Recipes prepared during different cultural ceremonies or festivals out of these food items are also discussed.
\end{abstract}

Keywords: Folk Culture, Garhwal Himalaya, Ethnic Food, Recipes, Food values, Medicinal Values, Ceremonial recipes.

\section{Introduction}

Garhwal Himalaya is rich in its cultural diversity since ages. Food being an important constituent of the culture is analysed here in view of its importance as availability, diverse recipe, nutritional and medicinal value and also its specific use during cultural ceremonies and religious functions. The people acquired knowledge of these food sources through ancient literature, manuscripts and experiences. Apart from its value as food, the folk also identified various plant sources as fodder, fibre, writing ink, useful cloth washers, tooth brusher, oilseeds and aromatic, etc. The knowledge of medicinal plants and their uses was first mentioned in Rigveda. Charak Samhita is a reservoir of this knowledge from where it was transcribed in various manuscripts written by the laureates of that time. Later it was converted in to a system of therapy known as Ayurvedic system of medicine.

India is the second largest populated country on the earth. Ever-increasing population is leading to shortage of resources. Millions of people in many developing countries are struggling hard even to meet their basic food requirement. Today, the most plant based human food depends on limited number of crops. The contribution of wild edibles cannot be ignored in any part of the world (Prescot-Allen and Prescott-Allen, 1990; Bussmann et.al., 2006; Pieroni et.al., 2007). Most rural inhabitants in India depend on the naturally available wild plant species to meet their food requirements as these species are 
enormous in nature and have a good nutritional value. In some of the wild edibles the nutritional value is much higher than several known common vegetables and fruits (Nordeide et. al., 1996; Sundriyal and Sundriyal 2001).

Indian subcontinent is having an affluent culture with all the three levels of biodiversity. Uttarakhand, which is known as Devbhoomi (Land of Gods) of India, is geographically distinguished into the Garhwal and Kumaun region and is endowed with rich biodiversity including medicinal, aromatic and spice plant species due to specific climate and geography. The anthropogenic literature indicates a large number of ethnic group inhabiting the region since long past as well as some recently migrated population. Amongst inhabitants distinct caste creeds culture and traditions existed from distinct past. Collectively all the people of hills are known as "paharis" and specific to Garhwal region as "Garhwalis". The present work is an attempt to document the traditional wild edibles consumed by the folk of the Garhwal region.

\section{Material and Methods}

Ethno-botanical survey on the use of plants as food and traditional medicines was conducted in Garhwal region using various approaches viz, pre-structured questionnaire interview and observation method. A structured dialogue with elderly people and Local Vaidyas was done for their knowledge about the traditional agricultural crops, practices and their benefits. The local and wild crops of medicinal relevance were collected from the adjoining forests in all seasons. Some scientific medicinal food or chemical composition values were correlated by reviews of literature. The plant specimens were identified (Gaur, 1999) and confirmed taking help of the taxonomists of HNB Garhwal University.

\section{Results and Discussions}

Food is an important aspect of culture which is also true for the peoples of mountain region in Garhwal Himalaya. Though an enormous number of plant species grow in this soil which are identified as food and medicines by the folk, a few of them are discussed in this paper that are specific to Garhwal region. Some of the nutritionally rich crops are Ragi (Mandwa), Amranthur, Ogal, Jwar, Maize, Rajma, Gahat, Bhatt, Urd, Suntha, Lobhiya, Moong, Til, Bhangjeera, Jau, Red Rice etc (Fig Plate 1). These traditional crops have deep connections with the cultural history of Garhwal region. Every crop has its own specific traditional recipes and significance. Some of these crops are cultivated in field while some grow in wild. These are rich source of minerals, vitamins and also have a medicinal relevance that helps in enriching the immunity also. Some important ethnic food of Garhwal folk are discussed here:

\section{Oryza sativa: Family -Poaceae ; Common name - Laal Chawal / Laal Chaal}


Most commonly used cereal in Uttarakhand is rice or Chawal. The term rice is derived from Tamil word "Arisi" (Hiziroglu et.al., 2007) and is commonly known as 'Dhan' in Hindi or 'Vrihi' in Sanskrit. It forms the basic economic activity for about 150 million rural households in India (Krishnaiah et.al., (2000). Ancient Indian literature "Charaka Sahita", authored by great Charaka mentioned rice with red husk and grain as the best which is efficacious and subdues the disease (Kumar, 1988; Krishnamurthy, 1991). Red rice, commonly used in Garhwal Region, is rich source of carbohydrate, protein, fat, iron and zinc. It is deeply knitted with traditional rituals and used in various folk dishes and snacks. The starch extracted from boiled rice is given to pregnant ladies and lactating mothers due to its caloric value. It is used to make biryani (khichadi), Metha Bhaat (Cooked in water with Gur/Jaggery) and Kheer. Red rice flour is cooked with jaggery to make traditional sweet of Garhwal known as "Arsa" which is a very specific sweet items prepared during wedding ceremony. Gangadharan et.al., (2018) reported that the land races of red rice possess higher nutraceutical properties than the other varieties, in the term of carbohydrate, protein, fibers, fat, iron and zinc composition. According to Se et.al. (2016) the red rice has low glycemic index and have high antioxidant level.

\section{Echinochloa frumentacea; Family - Poaceae; Common name - Jhangora}

Jhangora (Echinochloa frumetacea), a traditional dish of Garhwali folk which is also known as Indian barnyard millet is not only used as basic food item but is also used as specific dish during fasting and so is referred to as "Vrat ke chawal" in Hindi. These are also known as 'Shymaka' in Sanskrit.This is very important millet crop of the mountain region with growing demand in market because of its mediconutritional significance. It is used as an alternative of rice by the patients of sugar, gastric etc. It is used to make various dish needs like Kheer and Chhachinda (cooked Jhangora with butter milk). Chhachinda is very useful in Jaundice as it has low carbohydrate content and slowly digestible. According to Veena et.al.(2002), the Barnyard millet is a natural designer food. The millet has also been used to develop various by-products such as biscuits, sweets, noodles, rusk, etc. (Arora and Srivastava, 2002)). They are gluten free grains and hence can be consumed by everyone (Lee et.al, 2009 ).

\section{Eleusine coracana (L.); Family -Poaceae;}

\section{Common name - Koodu or Mandwa}

Ragi is known as Koodu or Mundwa in the mountainous area of Northern India. Also referred as 'Rajika' in sanskrit and 'finger millet' in English. This plant is of great cultural and geographical significance. The seed is highly nutritional and of great medicinal value. It is source of calcium, Iron, protein and vitamins for the poor as it is easily available. It is mixed with wheat flour to make chapatis that are preferably consumed with Ghee, Gur or mixed salt. It is 
mixed with warm to make "Baadi" which is easily digestible for elderly persons. Bread soup, pudding mixed with finger millet flour and wheat flour is beneficial for preventing diabetes, anaemia, gastric, constipation, migraine and osteoporosis (Pandey et.al, 2016).

\section{Hordeum valgare L.; Family - Poaceae;}

Common name - Jau.

In Sanskrit is known as 'Yava'. The powdered flour of Jau is mixed with wheat to make chapatis. It is also used as fodder for the livestock to increase milk yield. This is found useful in treatment of diabetes and eye disease. (Bisht et.al, 2013). "Jau" has also an important religious value as these are offered during prayer to God along with till (Sesamum indicum).

\section{Glycine $\max$ (L.) Merr. Family -} Papilionaceae; Common name- Kala Bhatt

Kala Bhatt is a variety of Glycine max and rich source of protein in the mountain. In combination with few other pulses it is used to make Dal. The seed of Kala Bhatt are roasted to Chutney. The aroma of the roasted seeds is gives relief during cold. Black soybean, a variety of Glycine max is cultivated as a food crop in the Garhwal region. The black bean is an important crop because of it high nutritional and medicinal value. The seeds are rich source of vegetable protein and fat. They are cholesterol-free, but contain linolenic acid, which has been found to prevent heart disease. Soybean contains isoflavonoids such as genistein and daidzein (Nakamura et.al, 2000; Lee et.al, 2004) that have been found to have antioxidant, antitumor, and estrogenic activity (Liao et.al, 2001; Takahata et.al, 2001). In India, the seed meal obtained after oil extraction is available in plenty, and is commonly marketed as Nutri-Nuggets.

\section{Macrotylome uniflorum (Lan.) ; $\quad$ Family -Fabaceae; Common name-Gahot.}

Horse gram in one of the highly nutritious vegetable pulse crop of warm efficacy. It is commonly known as Kulattha (Sanskrit) and Gahot (Garhwali). It is delicious and is having great medicinal relevance. It is given to patients of kidney stone. Regular consumption of the same helps in the breaking of stones. Apart from being a potential source of protein it is also recognized as an excellent source of iron, molybdenum and Calcium (Sreerama et al., 2012; Prasad et.al. 2010; Tuteja, 2008; Bhokre,rt.al., 2012).

\section{Vigna mungo; Family- Fabaceae; Common name- Urd.}

Vigna mungo is commonly known as Masha in Sanskrit, Black Gram in English and Urad dal in Hindi.This bean is heavy to digest and increases the moistness of body tissue. It is sweet to taste and hot in potency. 
1.
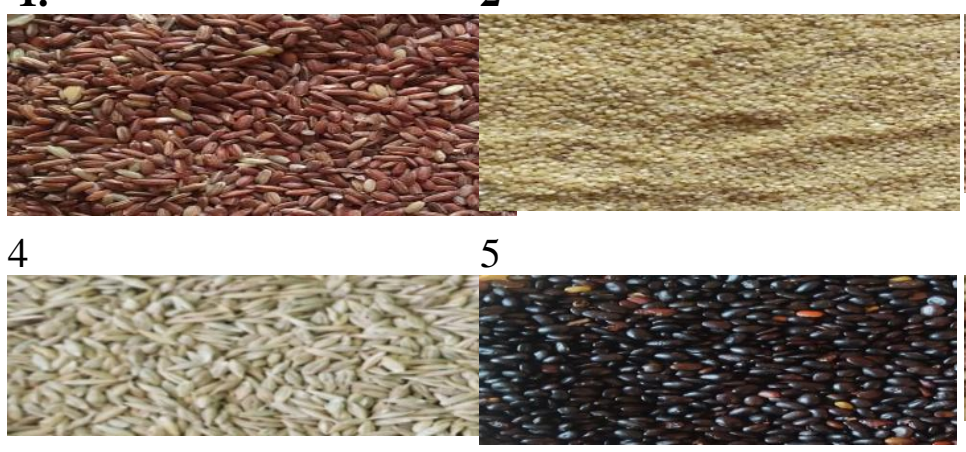

7

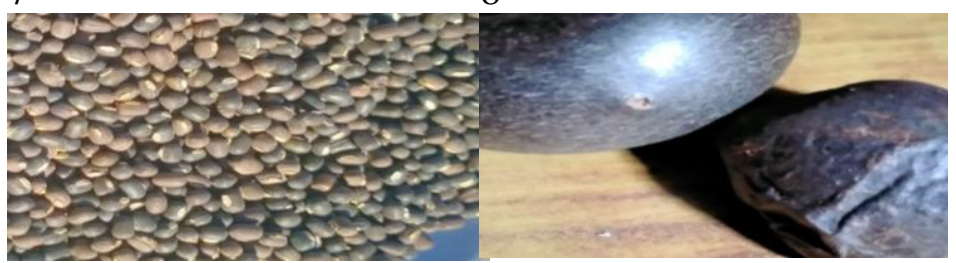

10

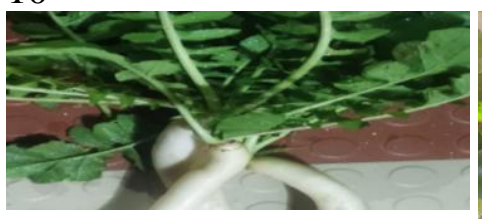

11

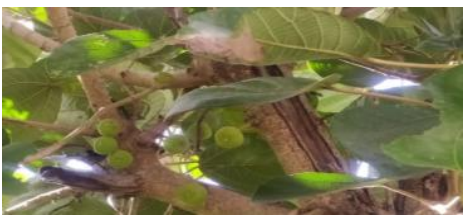

13

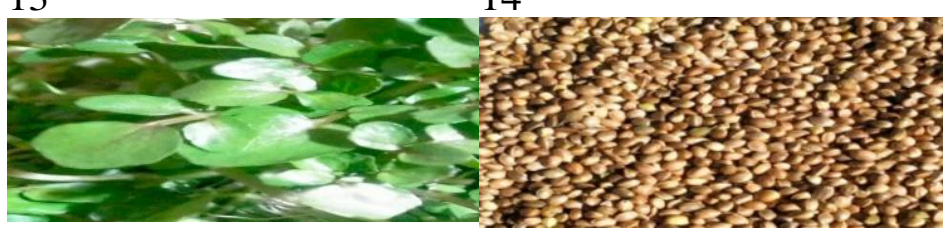

16

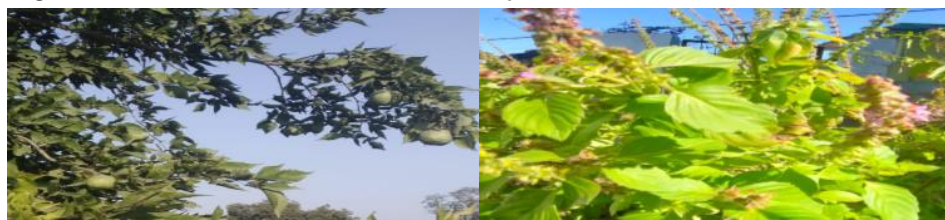

19

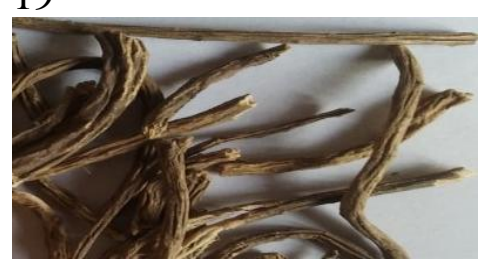

Fig Plate 1: Ethnic Food of the Garhwal Himalayan Folk
3

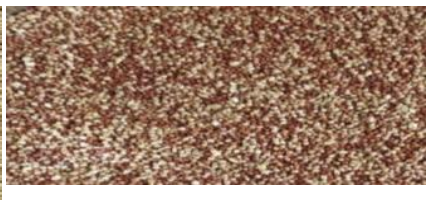

6

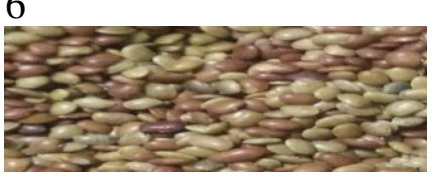

9

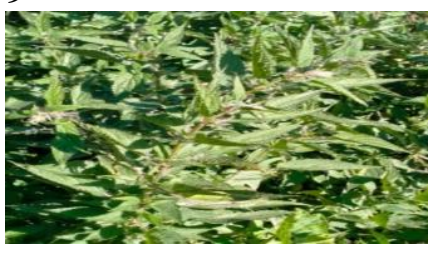

12

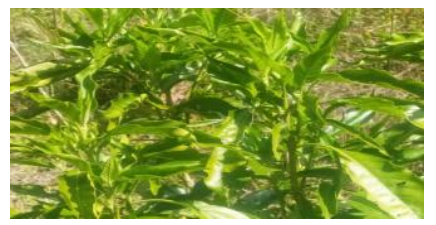

15

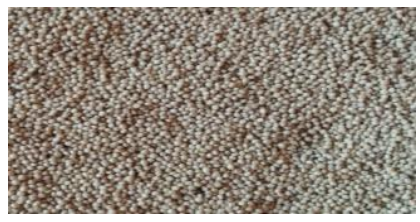

18

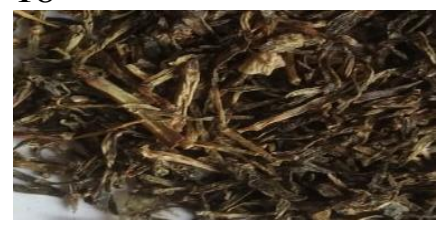

12. Adhatoda Vasica (Baisiga or Baisingu); 13. Celosia argentea (Gadria); 14. Cannabis sativa (Bhang); 15. Perilla frutescens (Bhangjeera); 16. Aegle marmelos (Belpatri);17. Ocimum gratissimum (Ram tulsi); 18. Allium stracheyi (Faran); 19. Angelica glauca (Choru). 
It is visualised that consumption of this bean increases kapha and pitta which causes many diseases and human health problems. It has some beneficial properties like enhancing milk secretion in lactating mothers and increases body weight and energy level. Urd has a warm efficacy with high consumptions in the mountainous region. Though urad dal is a very common dish in mountain region but It is specifically consumed as "Chainsa" which is prepared by making it in powder form as then it becomes easily digestible. It is rich source of calcium and is also used in plaster for fractured bones. The paste of Urd dal is used in making "Pakode" etc. on various religious occasions and birth day, marriages and functions.

\section{Dioscorea bulbifera L.; Family- Dioscoreaceae; Common name- Genthi}

Genthi is commonly known as wild Yam in English and Barahi in Sanskrit. It is a tuber climber vegetable that is commonly found in wild. The tubers are boiled in warm water. This vegetable is given to diabetic patients as its Regular use helps in lowering the sugar level. It also helps in the gastric problem. It is highly nutritious vegetable consumed mainly during winters and is useful in leprosy, asthma, cough, typhoid, tuberculosis, kidney dysfunction, contraceptive, constipation, indigestion, abdominal pain, dysentery, sore throat, wounds boils and cut, etc. Its tubers are roasted and cooked as vegetable. Tubers are also used for the treatment of purgative, aphrodisiac, rejuvenating and tonic anti-helmenthic, worm infestation, and general debility. It is also used in disease of lungs, spleen, diarrhoea, improving digestion and metabolism (Kala, 2005; Ahmed et.al, 2009; Abhyankar and Upadhyay, 2011; Khan and Kumar 2012; Chandra et.al, 2012).

9. Urtica dioica L.; Family - Urticaceae; Common name - Kandalee

In Garhwal folk language it is called kandalee. This is a under shrub of commonly occurrence in mountain region. It is of warm efficacy. The delicate branches leaves are eaten as vegetable during November to February months. It is also given to live stock for increasing milk quality. According to several authors (Tiwari et.al., 2010; Lahigi et.al., 2011; Kanakavalli et.al., 2014), the leaves and stems of this plant contain needle that injects several chemical including acetyl choline. Stem and leaves are applied externally for treating body cramps.

\section{Raphanus sativus Linn; Family - Brassicaceae; Common name - Muli;}

It is commonly known as 'Radish' in English and 'Mulaka' in Sanskrit. Radish green leaves are rich source of Iron, vitamin c, calcium. The roots are rich source of calcium and its juice is highly beneficial in colic pain. The juice of radish green leaf is highly recommended in treatment of Jaundice. Regular consumption of the fresh leaves of juice of leaves helps in recovery of 
damaged liver by local old peoples. It is used as vegetable salad.

\section{Ficus auriculata; Family - Moraceae; Common name - Temla}

It is commonly known as 'Udumber' in Sanskrit and 'Tirmul' in Hindi. It is a common tree found in mountain region. It fruits twice in a year. The fruits are roasted in mustard oil to make delicious vegetable. The ripe fruits are sweet in tastes and consumed raw. It is also useful in the gastric troubles. Combination of root powder of Ficus auriculata and bark of Oroxylum indicum is taken in Jaundice (Kunwar, 2006). Ethnic people in Kharagchari hill district use F. auriculata as food and medicinal plant ( Khatun et.al, 2016). The paste of leaves is applied on the wound for curing (Georg et.al, 2016). Phytochemical screenings of F. auriculata leaf and fruit extract were evaluated which showed the presence of phenols, flavonoids, glycosides, resins, tannins. Alkanoids are absent (Saklani and Chandra, 2012).

\section{Adhatoda Vasica; Family - Acanthaceae;}

\section{Common name - Baisiga or Baisingu}

Adhantoda zeylanica Medic. Syn A. vasica (Linn) and Justicia adhatoda (Linn) are commonly known as Malabur nut (English), Basinga in Garhwali and Vasika in Sanskrit. It is shrubby plant commonly visible during winter season. The delicate buds in its terminal plants are used for making vegetable. Before cooking the buds are left in water for 12-14 hours and then it washed properly to remove all bitterness. Decoction of Buds and leaf are given to diabetes patients and are also useful in fever. A. vasica is rich in essential oils, fats, resins, sugar, gum, amino acid, protein and Vitamin C. The plant leaves are said to contain phenols, tannins, alkenoids, anthraquinone, saponins and flavonoids, and reducing sugars (Bhat et.al. 1978; Pathak 1970).

\section{Celosia argentea; Family- Amaranthaceae; Common name- Gadria.}

It is commonly known as 'Sarwari' in Hindi, 'Vitunna' in Sanskrit and 'Quail Grass' in English. Gadrai is can use as a green vegetable that grows in the wild, mostly nearly water bodies. It is rich source of Iron and vitamins. It is mostly found in stream banks of hill-streams. Its leaves are cooked as vegetables in Garhwal region. Celosia argentea mostly found in winter season.

14. Cannabis sativa; Family - Cannabaceae; Common name - Bhang.

It is commonly known as 'Bhanga or Vijaya' in Sanskrit, 'True Hemp' in English. This is also shrubby plant that grows in wild. The seeds are used as Condiments. It is also used in making Chutney and "Crunchy Pakode". Seeds are used as spices and condiment. The seeds are used to make chutney. It is used in treatment of 
Cancerous ulcers, Tumors, diabetics, Epilepsy, gonorrhea (Kuddus, et.al, 2013).

\section{5._Perilla frutescens (L.); Family -Lamiaceae;} Common name - Bhangjeera

It is commonly known as 'Bhanijira' in Hindi and 'Perilla' in English. Bhang Jeera is a commonly occurring wild and domesticated shrub in the mountain. The seeds are of great medicinal value. The oil of seeds is used for baby massage during winters. The seeds are also used as spices and pasted as tasty sauce. The roasted seeds along with the flattened rice and sugar are locally known as "Bhukna" are consumed by localities during winter. Locally the plant is used for various purpose i.e as a medicine, edible oil, flavoring agent, as vegetable and other traditional food item. The roosted seeds are also useful in treating colds, cough, chest stuffiness, vomiting, abdominal pain, and constipation. Conventionally the seed oil is used as edible oil for centuries by local people and also used for massaging new born infants. The seed oil is used as a fuel, a drying oil, or cooking oil; the leaves are used as potherb, for medicine, or for flavouring (Publication and information Directorate 1966).

\section{Aegle marmelos (L) ; Family - Correa}

Rutacea; Common name - Belpatri

It is commonly known as 'Bel' in Hindi, 'Mahaphal' in Sanskrit and 'Bael tree' in English. This is wild edible fruit tree of medicinal and religious importance. The leaves of the tree (belpatra) are used in worship of Lord Shiva. The fruit juice is good for gastric problem. Regular consumption of juice helps in keeping bowel system healthy. It is also consumed in form of candy and murraba. Grounded fresh leaves to paste with 5-7 Piper nigrum and taken orally with water in early morning for curing diabetes, Peptic ulcer, diarrhea, constipation and jaundice (Virendra, et.al, 2018)

\section{Ocimum gratissimum L.; Family-} Lamiaceae; Common name- Ram tulsi.

It is commonly known as "Vridhu tulsi or Phaninjhak' in Sanskrit, 'Tulsi' in Hindi and 'Shrubby Basil' in English. Mostly Ram tulsi used in Garhwal region in a form of dry power (flower, seed, steam and leafs) in black tea and another used with in milk in winter season. Ocimum gratissimum is used as a spice and possesses nutritive value. Studies have proved that dry leaves have better disease preventive properties in comparison to fresh leaves. In India, the plant has a wide folklore medicinal importance and is used in treating diarrhea, headache, fever, pneumonia (Prabhu et.al, 2009). In South Asia, the whole plant is used in treating, Sunstroke, headache, stomache and influenza. Seeds are used against gonorrhea (Pandey et.al, 2017). The leaves are also used as a constituent of green tea. 
18. Allium stracheyi; Family Amaryllidaceae; Common name - Faran /Jamboo.

It is locally known as 'Jamboo' in Hindi and 'Faran' in Garhwal region. Generally it is used in pickles and treating some health problems. Traditionally Allium spp. has used as a spice by Bhotia tribal communities. Allium stracheyi and Allium wallichii with some other species are grown widely in Tibet and its adjoining borders in Uttarkashi and Pithoragarh District. Faran is also said to contain sulphur rich compound with anti-oxidant, anti-inflammatory and antimicrobial properties which reduces the blood cholesterol.

\section{Angelica glauca; Family- Apiaceae;} Common name - Choru.

In trade, it is called 'choru', 'Gandrayan' and Himalayan Angelica. It is commonly known as Choru in Garhwal region and Gandrayan in Kumaon area. In literature, it is cited as smooth Angelica (Chorak in Sanskrit) and Tsar on (in Tibet). Angelica is used as a cough syrup. 2-3 whole angelica roots are boiled in quart of water to which honey is added to make it a syrup consistency. Choru roots are given with fodder to improve lactation in cattle.

Traditional food crops forms a significant portion of dietary diversity of farmer households of Uttrakhand hills. These foods are associated with the culture and traditional customs and festivals of the region. As Uttarakhand has a strong food culture, traditional food systems can persist and wild foods are still prevalent enough. These crops and practice help in improving local food security in a sustainable manner. These crops are rich in many important nutrients and resilient to disease and droughts etc. The traditional practice of using these crops as mixed cropping provided protection against total crop failure. It is well recognized fact that wild species and intra species biodiversity have a key role in nutrition security. These crops plays an imperative role in rural areas, and apart from their food value these are still being used as household remedies for different ailments (Baluni, 2015; Baluni and Chandola, 2019; Baluni et.al, 2020,2021).

\section{References}

Abhyankar RK, Upadhyay R (2011). Ethno medicinal studies of tubers of Hoshangabad, M.P. Bulletin of Environment, Pharmacology and Life Science Vol.(1):57-59.

Ahmed Z, Chishti ZM, Ram G, Johri RK, Bhagat, A, Gupta KK, Ram G(2009). Antihyperglycemicand Antidyslipidemic activity of aqueous extract of Dioscorea bulbifera tubers, Diabetologia Croatica, 38-39.

Arora S and Srivastava S (2002). Suitability of millet-based food products for diabetics. Journal of food Science and Technology. 2002:39: 423-426. 
Baluni P and Chandola A (2019). Preliminary survey of riparian vegetation of the spring-fed stream Kyunja Gad, A tributary of river Mandakini, Rudraprayag Garhwal, Uttarakhand. J. Mountain. Res. 14: 67-69.

Baluni P and Kuriyal SK (2020). Ethno-Medical documentation of plants used by the rural folk of Pauri and Kot Blocks in District Garhwal, Uttarakhand. Journal of Mountain Research 15: 91-95.

Baluni P (2015). An insight into the use of rare medicinal plants by the rural folk of Chamoli Garhwal. J. Mountain. Res. 10: 21-28.

Baluni P, Kuriyal SK, Dobriyal Kusum (2021). Traditional Use of wild medicinal plants by the folklore of Garhwal Himalayan: A case study from Jaiharikhal Block in Pauri Garhwal, Uttarakhand. J. Moutntain Res. 16(1): 137-142.

Bhat VS, Nasavati DD, Mardikar BR(1978). Adhatoda vasica-an Ayurvedic plant. Indian Drugs 15: 62-6

Bhokre C, Ghatge PU, Machewad G, Rodge A (2012). Studies on prepration of buns fortified with germinated horsegram flour. Scientific Reports 1(1): 127.

Bisht VK, Negi JS, Bhatt A.K., Sundriyal RC (2013). Traditional use of medicinal plants in district Chamoli, Uttrakhand, India. Journal of Medicinal plant Research, 7(15): 918-929.
Bussmann, R.W. and Sharon, D.(2006). Traditional medicinal plant used in Northern Peru: tracking two thousand years of healing culture. J. Ethno. \& Ethnomed. 2: 47.

Chandra, J., Joshi, H., Bahuguna, P., Kedia, V.K., Kumar, R. and Kumar, Rakesh (2016). Behavioral effects of high altitude medicinal plant in rats. Sch. Acad. J. Pharm., 5(9):377-382.

Chandra S, Saklani S, Mishra PA, Bamrara A (2012). Nutritional profile and phytochemical screening of Garhwal Himalaya medicinal plant Dioscorea bulbifera. International Research journal of Pharmacy. 3(5): 289-294.

Gangadharan S, Chinnamuthu C R, Babu R, Baskar K, Vanniarajan C (2018). Analysis of nutritional and cooking quality parameters of red rice cultivator using scanning electron microscope with Edax. International Journal of Agriculture Science 10: 5473-5476.

Gaur R D (1999). Flora of District Garhwal: North West Himalaya (with Ethno-botanical Notes).Transmedia publication, Srinagar (Garhwal).

George M, Joseph I, Paul M N (2016). Ficus auriculate, a pharmacological update. Int. J. Curr. Res. Acad. Rev. 4: 26-31.

Hiziroglu S, Piyawade B, Vallayuh F, Worakit S, Songklod J (2007). Selected properties of medium density fibreboard (MDF) 
panels made from bamboo and rice straw. Forest Products Journal. 57 (6): 46-50.

Kala PC(2005). Ethnomedicinal botany of the Apatani in the Eastern Himalayan region of India. Journal of Ethnobiology and Ethno medicine:1: 11.

Kanakavalli, K., Thillaivanan, S., Parthiban, P., Vijaylakshmi, G., Sudha, M., Sutha, J.(2014). Anti-hyperlipidemic herbs in Siddha system. Pharmaceutical Science. 4:541-545.

Khan, J. A., Kumar, S. (2012). Ethno medicinal uses of some medicinal plant used for snake bite in Pooch district of Jammu and Kashmir (North Western Himalaya) India. Life science leaflets 10: 123-132.

Khatun MM, Rahman MM, Rahim MA, Jakariya, M., Mirdah, M.H.(2016). Study on the ethnobotany and nutritional status of three edible ficus species in hill district of Bangladesh. Int. J. Min. Fruits, Med. Arom. Plant 2(1): 35-40

Krishnaiah, K. and Janaiah, A. (2000). The role of rice in Indias food security- projects and future diretions. India Grain, 2(11), 27.

Krishnamurthy KS (1991). The Wealth of Sursuta. International Institute of Ayurveda, Coimbatore, Tamil Nadu, India. pp582.

Kuddus, M., Ginawi, I.A. and Al-Hazimi, A. (2013). Cannabis sativa: an ancient wild edible plant of India. Emirates Journal of food and Agriculture, 25(10): 736746.

Kumar S, Joshi H, Chandra J, Bahuguna P, Kedia VK, Kumar R (2015). Effect of Allium stracheyi on behaviour of zebra fish: a pharmacological approach. Sch. J. App. Med. Sci., 3(9D):3356-3363.

Kumar TT (1988). History of Rice in India. Gian Publishers,Delhi, India. 241 pp.

Kumari P, Singh BK, Joshi GC, Tewari LM (2009). Veterinary ethno medicinal plant in Uttrakhand Himalaya region, India. Ethnobot. Leaflets. 13:1312-1327.

Kunwar, R.M. and Bussmann, R.W.(2006). Ficus species in Nepal : a review of diversity and indigenous uses. Lyon. 11(1):85-97.

Lahigi, S.H., Amini, K., Moradi, P. and Asaadi, K.(2011). Investigating the chemical condition of different plant extracts of bipod nettle Urtica dioica L. in Tonekabon region. Journal of Physiology. 2(1): 337-340.

Lee J, Renita M, Fioritto RJ, Martin ST, Schwartz, S.J. and Vodovotz Y. (2004). Isoflavone characterization and antioxidant activity of Ohio soybean. $J$. Agric. Food Chem. 52: 2647-2651.

Lee RA, LD Ng, Dave E, Ciaccio JE, Green, R.H.P.(2009). The effect of substituting alternative grains in the diet on the nutritional profile of the gluten free diet. 
Journal of Human Nutrition and Dietetics, 22(4): 359-363.

Liao, H.F., Chou, C.J., Wu, S,H., Khoo, K.H, Chen, C.F and Wang S.Y. (2001). Isolation and characterization of an active compound from black soybean and its effect on proliferation and differentiation of Human leukemic U937 cells. Anticancer Drugs 12: 841-846.

Nakamura, Y., Tsuji, S. and Tsuji, S and Tonogai, Y. (2000). Determination of the level of isoflavonoids in soyabean and soy-derived food and estimation of isoflavoinoids in Japanese daily intake. J. AOAC Int. 83: 635-650.

Nautiyal, S., Rajan, K.S., Shibasaki, R.(2004). Environmental conservation vs compensation: explorations from the Uttarakhand Himalaya. Environ. Inform Arch, 2: 24-35.

Nordeide, M.B., Hatloy, A., Folling, M., Lied, E. and Oshoung, A. (1996). Nutrient composition and nutritional importance of green leaves and wild foods in an agricultural district, Koutiala, in Southern Mali. Int. J. Food Sci. Nutr. 47 (6): 455-468.

Pande P C (1999). Kumaon mein prachalitpaudhon ke sthaniya namo ki vyautpatti. In Ethnobotany of Kumaon Himalaya. In: Pande PC, Pokharia DS and Bhatt JC (Eds) Scientific Publishers, Jodhpur, (India); 253-262 pp.
Pandey NC, Chopra N, Joshi GC, Tewari TM (2016). Agro diversity and etnobotanical distribution: A case study of Tarikhet Block, Kumaun Himalaya. Int. J. Bot. Stud. 1(5): 32-41.

Pandey S, Shukla A, Pandey S (2017). Pandey A. An overview of resurrecting herb 'Sanjeevani' (Selaginella bryopteris) and its pharmacologicall and ethnomedicinal uses. The Pharm. Innov. 6: 11-14.

Pathak, R.P.(1970). Therapeutic Guide to Ayurvedic Medicines. A handbook on Ayurvedic Medicines Vol.1: Shri Ramdayal Joshi Memorial Ayurvedic Research Institute; :pp.121.

Pati, C.K. and Bhattacharjee (2013). Seed potentiation of horsegram cultivar by herbal manipulation. International $J$. Medicinal Plant Res. 2(1): 152-155.

Pieroni, A., Houlihan, L., Ansari, N., Hussain, B. and Aslam, S. (2007). Medicinal perception of vegetables traditionally consumed by south-Asian migrants living in Bradford, Northern England. J. Ethnopharmacol. 113: 100-110.

Prabhu, K.S., Lobo, R., Shirwaikar, A.A., ShirwAaikar, A. (2009) Ocimum gratissimum: A review of its chemical, pharmacological and ethnomedicinal properties. Open Compl. Med. J. 1: 1-15. Prasad, R.C., Upteri, R.P., Thapa, S., Jirel, L.B., Shakya, P. R. and Mandeal, D.N. (2010). Food security and income generation of 
rurel people through the cultivation of finger millet in Nepal. In: Mal B, Padulosi S and Bala Ravi S (Eds)., Minor millets in South Asia. 107-146 pp.

Prescott-Allen, O.C. and Prescott-Allen, R.(1990). How many plant feed the world? Conservational Biology. 4: 365374.

Publication and Information Directorate. (1966). The wealth of India. vol. 7. New Delhi

Saklani S and, Chandra S (2012). In vitro antimicrobial activity, nutritional profile and phytochemical screening of wild edible fruits of Garhwal Himalaya (Ficus auriculate). Int. J. Pharma. Sci. Rev. Res. 12(2): 61-64.

Samal PK, Dhyani PP, Bollo M (2010) Medicinal plant resources in Nanda devi biosphere reserve in Central Himalayas. Indian J. Tradit. Know. 9: 140-144.

Se C H Chuah K A, Mishra A, Wickneswari R (2016). Evaluating crossbred red rice variant of postprandial glucometabolic responses: A comparison with commercial varieties. Nutrients 8: 308.

Singh K J , Thakur AK (2014). Medicinal plant of the Shimla hills, Himanchal Pradesh: A survey. International Journal of Herbal Medicine, 2(2): 118-127.

Sreerama YN, Sashikala VB, Pratape VM, Singh, V (2012). Nutrients and antinutrients in cowpea and horsegram flours in comparison to chickpea flour: Evaluation of their flour functionality. Food Chemistry 131: 462-468.

Sundriyal M, Sundriyal RC (2001). Wild edible plants of the Sikkim Himalaya: Nutritive value of the Sikkim Himalaya: Nutritive value of selected species. Economic Botany. 55: 377-390.

Takahata, Y., Ohnishi-Kameyama, M., Furuta, S., Takahashi, M. and Suda, I. (2001). Highly polymerized procyanidins in brown soybean seed coat with a high radical- scavenging activity. J. Agric. Food Chem. 49: 5843-5847.

Tiwari J K, Ballabha R, Tiwari P (2010). Ethnopaediatric in Garhwal Himalaya, Uttrakhand India (Physiomedicine and Medicine). New York Science Journal 3(4):123-126.

Tuteja U (2008). India's pulse production: Stagnation and Redressal. pp.29.

Veena B, Chimmad BV, Naik RK, Shantakumar G (2005). Physio-chemical and nutritional studies in barnyard millet. Karnataka J. Agril .Sci. 18(1): 101-105.

Virendra T, Rashmi S, Pandey AK (2018). Aeglemarmelos: pharmacological, medicinal importance and conservation in India. Journal of Experimental Zoology, India, $21 \quad$ (1): 11-18. 